\title{
Freedom of Expression, Privacy, and Ethical and Social Responsibility in Democracy in the Digital Age
}

José Poças Rascão, Polytechnic Institute of Setúbal, Portugal

iD https://orcid.org/0000-0003-2448-2713

\begin{abstract}
This article reflects on freedom of expression, privacy, ethical and social responsibility, in the context of social networks, in the context of the experience of democracy in cyberspace. It asks questions about ensuring the protection of privacy, freedom, and autonomy of internet users in the internet environment. It identifies national and international legislation that guarantee the right to privacy and the protection of citizens' personal data. It reviews the literature on the concept of ethics and social responsibility, in democracy, in the digital age, associating this domain of knowledge with the concept of privacy, freedom, and ethical and social responsibility, in the context of social networks. The article discusses the concepts that guide this theme and that are directly involved with related domains. It is alert to the need for ethical and legal protection of the digital data of internet users, aiming at the autonomous safeguarding of their digital identities.
\end{abstract}

\section{KEYWORDS}

Ethical and Social Responsibility, Freedom of Expression, Privacy

\section{RESEARCH THEME AND PROBLEM}

Freedom of Speech, Privacy, Ethical and Social Responsibility, in Democracy, in the Digital Age, are inherent rights to all human beings, regardless of race, creed, sex, nationality, ethnicity, language, religion or any other condition. As such, rights are not merely privileges granted, by other human beings, but rights inherent to the status of the human being, and for this reason, they cannot be restricted at the whim of someone.

Human rights are an integral part of the essence of man, and fundamentally, as a social and gregarious being, they have a determining role in maintaining, harmonizing and safeguarding freedom, peace and justice, among individuals, so that they feel protected from abuse, such as discrimination, intolerance, injustice, oppression and slavery that can arise in this coexistence, as well as feeling willing and free to assume the dignity of human beings. 


\section{GOALS}

This article aims to present a general picture of the evolution of the right to Freedom of Expression, Privacy, Ethical and Social Responsibility, in Democracy, in the Digital Age, being extremely sensitive to the behavioral changes of society. Recognizing privacy, as a volatile legal object, the article seeks to demonstrate that the context, in which the subjects of the right to privacy are inserted, is essential for its effectiveness.

Deductively, the work starts from the first steps of the right to privacy, as an autonomous figure, reaching the current interpretation by the organs of power. The text demonstrates the negative dimension of the right to privacy, that is, the one that protects the privacy and privacy of the individual, against the intrusions of public power and other citizens, and the positive dimension, where the State is obliged to implement administrative and legislative measures to guarantee citizens' privacy, protecting them from the actions of other citizens and the State itself, especially in technological circles.

\section{APPROACH METHODOLOGY}

The complexity and turbulence of the information and knowledge society have taken interdisciplinarity and transdisciplinary into consideration, as processes essential to the development and innovation of sciences and technologies. The implementation of these concepts in some areas faces challenges that go through not only the very polysemy of these terms, but also the rigid visions arising from the very dominant disciplinary training and tradition.

It is necessary to understand, through a theoretical review, the history of fundamental human rights, through historical reference documents; a psychosocial analysis of the concepts of Freedom and Privacy; the regulatory framework in which they fit; the Internet, as a platform for exercising rights and freedoms and the associated problems; digital data, the trail of people; the surveillance of citizens; the social engineering of Power; online social networks and spaces of trust and conflict.

It is a descriptive and analytical approach, seeking to know and analyze the existing cultural and scientific contributions on these subjects, based on the review of the existing literature. The research was structured based on the systemic approach for understanding the problems of Freedom of Expression, Privacy, Ethical and Social Responsibility, in Democracy, in the Digital Age.

\section{FUNDAMENTAL CONCEPTS}

\section{Freedom of Expression}

Communication is a fundamental process for human interaction. Until today, there is no certainty about how primitive men began to communicate with each other, whether by shouting, whether by grunting, whether by gestures, or by the combination of these elements. It is also through it that human beings acquire awareness of themselves and others, internalize, produce, reproduce and transmit to others, through language, the behaviors, values, norms, and their meanings, in society and culture, in which it is inserted.

The communicational process takes place through language, namely through expression, oral and written. It has been diversifying, over time and space, inventing new channels, from rock paintings, drum sounds, smoke signals, paper, telegraph, telephone, radio, television, and today with the internet, it allows men communicate with each other in a faster and easier way.

Communication is the basis of interaction in the human relationship, and it is also the foundation of the right to free thought and free expression of man. Freedom of thought and freedom of expression are two associated rights, since the two complement each other. However, both have freedom, with a somewhat different nature. Freedom is a concept that contains, an option or will and a constraint, the conflict with the freedom of another person. One person's freedom ends when another's freedom begins. 
Thinking can be defined as the act of thinking, becoming aware, reflecting or meditating; faculty to conceive, to combine and compare ideas; particular act of the mind, the result of which is reflection; way of thinking; opinion, point of view; act of meditating and fantasizing. Thought, given its rational and exclusive nature of man, is a manifestation of human subjectivity, a phenomenon reserved for the individual's own mind. In this way it can be considered or represented, as a non-action in the sense that it does not directly affect others, except, when manifested or expressed, by a communication action (speaking, writing, acting, etc.).

The expression is a concrete action, a communication, an objective manifestation of thought, since the nature of the interaction is always in relation to the other, that is, the expression is the external and objective manifestation of our thought, about others. Freedom of expression is not absolute, because it can be limited in its action, when in its full exercise it runs the risk of colliding with other individual freedoms, namely, the right to honor, moral integrity, image, good name and reputation.

Freedom of expression is the right of anyone to freely express personal opinions, ideas and thoughts, without fear of retaliation or censure by the government or other members of society. It is a fundamental concept in modern democracies, in which censorship does not exist (Cabral, 2010). Freedom of thought and expression are the two main vectors of representative democracies, which are in harmony with other rights: the right to information, the right to contest insofar as, for citizens to participate in choosing a government, they have to to be able to access information or ideas, expressed publicly - public opinion, contest them, if that is their will and make their judgment, about them in order to be able to make a choice, namely a choice in the context of elections.

Freedom of expression is a legally protected right in democratic societies, in fact, it legitimizes them, being prescribed in article 19 of the 1948 Universal Declaration of Human Rights. Everyone has the right to freedom of opinion and expression, which implies the right not to be disturbed by their opinions and to seek, receive and disseminate, regardless of borders, information and ideas by any means of expression. (Universal Declaration of Human Rights). Everyone has the right to freely express and disseminate their thoughts by word, image or any other means, as well as the right to inform, to inform themselves and to be informed, without hindrance or discrimination.

\section{Privacy}

The concept of privacy was born in ancient philosophy, with the distinctions between the public and private domains. In ancient Greece, the interest of the state was superior to the private interest. With the decline of Greek political life, after the Macedonian invasion, the philosophical interest shifted from public to private life, thus valuing the citizen's intimacy. With the decline of feudal society, in which isolation was the privilege of a few, privacy began to be extended to all, as an element to promote equal treatment, between citizens and social parity. In America and Europe, until the first half of the 19th century, the defense of the right to privacy was confused with that of private property and honor, but from the second half of the 19th century onwards, the protection of privacy took on new shapes.

In the 20th century, technological innovations brought about sudden changes in the concept of privacy, raising the risk of breach. The desire to obtain information about people has grown. (Navarro, 2014) In 1948 the American Declaration of the Rights and Duties of Man appeared, international protection of the right to privacy, which in Article 5, provides the following: "Everyone has the right to the protection of the law against abusive attacks on his honor, your reputation and your private and family life". Second, Sampaio, (1998), in the same year, was approved by the General Assembly of the United Nations on December 10, the Universal Declaration of Human Rights, which enunciated in its art. 12, that "no one will be the object of arbitrary interference with their private life, family, home or correspondence, nor attacks on their honor or reputation. Everyone has the right to the protection of the law against such interference or attacks". 


\section{Ethic}

According to Du Mont (1991), ethics aims to establish principles of human behavior that help people choose alternative forms of action. These considerations lead to definitions of ethics and morals, prompting us to refer to deontology as the study of the codes or ethics of the professions. Targino (2006, p. 135) states that the definitions of ethics originate from the "Greek term ethos, as etymology suggests, it is the part of philosophy that deals with the reflection on customs, encompassing guidelines". While the moral "Latin term mores refers to acts and customs per se, that is, the set of objective norms of conduct, changeable in time and space".

According to Sá (2007), the word ethics is sometimes associated with the sense of morals, but not always in an appropriate way. It has also been understood as the science of human conduct towards being and its fellow beings, to study the action of men and their considerations of value. In this research, we emphasize its importance for legal professionals, highlighting ethical performance in the context of today's society and, especially, about their social responsibility.

With a view to the theoretical foundation of the study, we approach the theme of professional ethics linked to the code of ethics, studied by deontology which, according to Targino (2006, p.135) "comes from the Greek deontos, duty; logos, discourse or treatise, etymologically equivalent to treatise or science of duty".

\section{Social Responsibility}

For Du Mont (1991), social responsibility is an ethical concept that involves notions of change, of how human needs must be met. In addition, the author emphasizes the interest in the social dimensions of the information service, which has to do with improving the quality of life. Organizations around the world have considered themselves socially responsible for several decades. Social responsibility has gained more prominence since the 1990s, with a greater influence of society, in the media and NGOs, that is, in the organizational world.

Apparently, there was a need to give a positive corporate image, in order to make up for lost time. Despite the debates and the concept being widely used, social responsibility is still confused with welfare, which assumes a personal character represented by donations or the creation of philanthropic foundations, as Cajazeiras (2006, p. 13) sees, "another conception of social responsibility very linked to the idea of donation - the philanthropic phase".

Social responsibility surpasses the paradigm of assistance, which in a certain way limits the performance, repercussion and monitoring by society. This change is due to industrial advances, globalization and the intense flow of information and technologies, causing the degradation of quality of life, the intensification of environmental problems and the precariousness of labor relations. As a result, society began to develop attitudes to solve its problems and the high echelons to adhere to social responsibility, often under pressure from the consumer code.

Thus, the social responsibility of judicial institutions is directed to act in an ethical and transparent manner, with attitudes that revert to improving the quality of life of the citizens in which they are inserted, even mitigating environmental problems (Veloso, 2006). Acting with social responsibility is not just acting in the institution's marketing. It is going beyond interests that aim at personal or group interests, because any institution that considers itself responsible, must have the capacity to attend the interests of the different parties - state, collaborators, service providers, citizens, community, government, institutions and environment.

\section{Democracy}

Democracy is the political regime in which sovereignty is exercised by the people. The word democracy comes from the Greek demokratía, which is composed of demos (meaning people) and kratos (meaning power). In this political system, power is exercised by the people through universal suffrage. It is a government regime in which all the important political decisions are with 
the people, who elect their representatives through the vote. It is a government regime that can exist in the presidential system, where the president is the greatest representative of the people, or in the parliamentary system, where there is the president elected by the people and the prime minister who makes the main political decisions.

Democracy is a government regime that can also exist, in the republican system, or in the monarchical system, where there is an indication of the prime minister who really governs. Democracy has principles that protect human freedom and is based on the rule of the majority, associated with individual and minority rights. One of the main functions of democracy is the protection of fundamental human rights, such as freedom of expression, religion, legal protection, and opportunities to participate in the political, economic, and cultural life of society. Citizens have the express rights, and the duties, to participate in the political system that will protect their rights and their freedom.

The concept of democracy has evolved over time, and from 1688, in England, democracy was based on freedom of discussion within parliament. According to some 18th century philosophers and thinkers, democracy was the people's right to choose and control the government of a nation. In some countries, the evolution of democracy occurred very quickly, as in the case of Portugal and Spain. Despite this, this rapid evolution has created political insecurity. In countries like England and France, a slow evolution of democracy has resulted in the development of stable political structures.

Social democracy is the designation of political parties and currents with Marxist tendencies that arose before World War I. This type of political ideology is based on Marxism and principles such as equality and social justice, solidarity and freedom. Social democracy proposed a change in capitalist society, using gradual and never revolutionary methods, according to the norms of the parliamentary and democratic system.

Ancient Greece was the cradle of democracy, where, mainly in Athens, government was exercised by all free men. At that time, individuals were elected, or draws were made for different positions. In Athenian democracy, popular assemblies existed, where proposals were presented, and free citizens were able to vote.

Racial democracy is directly related to the problem of racism and discrimination and suggests that Brazil has managed to deal with and resolve these problems in a way that other countries (such as the United States) have not. Racial democracy addresses the relationships between different races and ethnicities in Brazil. Democracy can be direct or pure democracy, when the people express their will by direct vote. Representative or indirect democracy, the people express their will by electing representatives who make decisions on their behalf.

The main differences between democracy and dictatorship are:

- Model of elections: In democracy, elections are direct, that is, the people themselves vote. In dictatorship, elections are indirect, in which governors are chosen through an electoral college;

- Type of State: In democracy, the type of State is democratic, while in a dictatorship the State is authoritarian and totalitarian;

- Division of powers: In democracy, there is a division of powers. The legislature, the executive and the judiciary function independently from each other. In the dictatorship, the powers are concentrated in the hand of a single person or group;

- Protection of rights: A democratic state protects and ensures the rights of citizens, in addition to constantly legislating new rights. In a dictatorship, rights are often violated;

- Popular demonstrations: Popular demonstrations are common in democracy, considering freedom of expression. A dictatorial government often uses censorship to prevent popular demonstrations, news or any type of communication contrary to its ideals. 


\section{THEORETICAL-METHODOLOGICAL FRAMEWORK FOR RESEARCH}

\section{Freedom, Privacy and Justice in the Digital Age}

In 1873 the American Judge Cooley defined privacy as: “The right to be let alone", or as a person's right to be left alone, to be alone. (Silveira, 1997). This right would include the immunity of people in the face of the action of reporters, photographers or people who use any "modern" devices for recording or reproducing sounds and images. Lawrence Lessing, a contemporary scholar on the subject, defines privacy as everything that "is the product of a relationship between everything that can be monitored or investigated, and all the legal protections and structures used to hinder this monitoring and / or investigation" (Finkelstein, 2011).

The American Federal Constitution does not privilege the Right to Privacy. Only a few state constitutions, such as Alaska (1972), Arizona (1912), South Carolina (1970), safeguard the right to intimacy and privacy. Bearing in mind that the American judicial system belongs to Common Law, court decisions make law between the parties, with the Right being guided by intimacy. There are several jurisprudential manifestations on the limit of access to American private life, among them: The first case is the emblematic Griswold v. Connecticut, 381 U. S. 479 (1965), in which it was asked to what extent the government could interfere in the intimate life of a couple in order to decide on contraceptive methods.

William Douglas (1898-1980), affirmed that many of the rights and guarantees not expressly provided for in the Bill of Rights could be extracted hermeneutically from the "penumbras" formed by "emanations" that flowed from other protections of the Constitution itself, having emerged the "right to privacy" (right to privacy) that was not expressed in the American Constitution. Arthur Goldberg (1908-1990) countered, saying that the introduced Amendment allowed the expansion of other rights than those expressly enshrined in the constitutional text. Thus, the State could not intervene in sexual life, nor in the deprivation of intimacy. Another important case of the Right to Privacy is reported by Stanley v. Georgia, 394 U. S. 5574 in 1969. In this case, the "right of intimacy" was further expanded. The police, armed with a court order, entered Robert Stanley's home in search of evidence that he was "gay". The police found three pornographic films. Stanley was convicted of possession of obscene material.

Thurgood Marshall (1908-1993), alludes to the American ideal of "the search for happiness" and invokes Louis Brandeis' famous vote (1856-1941) in Olmstead v. United Sates, 277 US 438, 478 (1928), when it synthesizes the "right of privacy", as "the right to be alone", "the most comprehensive of rights and the right most valued by civilized men" (the most comprehensive of rights and the right most valued by civilized men). The State was not denied the power to regulate obscenity. But, no doubt, this power did not reach the individual, in his own home. Violated the right of privacy remained.

The theme that has frequently agitated the American courts is the right of the press to divulge facts about people's private lives. It is often difficult to reconcile press freedom with the individual's right to privacy. The Supreme Court has understood that if the fact reported was obtained through a public source and narrated with veracity, it is constitutionally supported by freedom of the press. There is a precedent that has served as a guide for the case of disclosing truthful information, of public interest: Cox Broadcasting Corp. v. Cohn, 420 U. S. 469 (1975).

In 1971, in a city in Georgia, a 17-year-old girl was raped and murdered. State law prevented the media from disclosing the rape victim's photo and name. A WSB-TV reporter obtained a copy of the file from a court official and released the data. The victim's father, based on state law, filed a lawsuit demanding punishment and compensation. In the Supreme Court, by a majority, the law of the State of Georgia was declared unconstitutional. The right to freedom of the press prevailed over the victim's right to privacy.

According to Byron White (1917-2002), in his explanation of vote he stressed: "The news by the media is an important source for citizens to be able to inspect governmental activity". On the other hand, in the specific case, the information was already publicly registered. The limits of the right to 
privacy are constantly being tested. In January 2012, the Supreme Court unanimously ruled that the installation of Global Positioning System (GPS) trackers in the vehicle was unconstitutional, without the owner's consent or judicial authorization, for the purpose of monitoring the driver's movements by the police, as well as such as installing a computer program that detects illegal files on the citizen's computer, without the investigated citizen noticing the investigation.

According to Brandão, (2013), The problem between the right to privacy and the new information and communication technologies is not unique to contemporary times. When Warren and Brandeis (1890) wrote the article The Right to Privacy, their concern was with the new technologies of the time, such as cameras and big newspapers.

The Constitution of the United States of America (1787) "is the oldest written National Constitution in use and that defines the main bodies of government, their jurisdictions and the basic rights of citizens." (A Brief History of Human Rights - The Constitution of the United States of America (1787) and the Bill of Rights (1791).

The French Declaration of Human Rights emerged in the context of great political and social upheaval, under the Enlightenment influence of natural rights and Renaissance ideas that evoked equality among all human beings, calling into question the old ideals. The Bill of Rights (1791) “... protects freedom of expression, freedom of religion, the right to keep and use weapons, freedom of assembly and freedom of petition." (A Brief History of Human Rights - The Constitution of the United States of America (1787).

According to Brandão (2013), in 1974 Federal Privacy was published, a federal legislation that started to govern, within the restricted scope of federal government agencies, the management activities of stored personal data, allowing the disclosure of individual information with some restrictions and expanding the interested party's access to personal data (right of access), including for the purpose of requesting their change (right of rectification). Agencies are obliged to follow, among others, the principles of collecting, only information essential to their activities, of publishing news about the nature and structure of the database, in the Federal Register and, not keeping information about, how the person exercises their individual rights.

According to Camara, (2014), in American law, the problem of the potential violation of the provisions of the privacy protection law in the electronic media, the Electronic Communications Privacy Act of 1986 ("ECPA"), has been the subject of intense debate. In the case of Google, the AdSense technology associated with Gmail email messages would not be compatible with the rules of the law, related to crimes of electronic interception and unauthorized access to content stored on the Internet. The jurisprudence, however, seems to have little depth on the topic, supporting the nonapplication of ECPA rules, to data storage services in electronic communication. Thus, the argument was taken to the extreme, messages received and sent and temporarily stored on Gmail's servers would be excluded from the scope of protection of the law, above all due to the privacy of users located in different North American federated states.

According to Lucca, (2008), in March 2004, Google started testing its electronic mail service, "G-Mail", becoming the center of controversies in the debate on privacy and protection of data and personal information of internet users. This contributed to the first lines of state laws in the United States on "online privacy", the California online Privacy Protection Act of 2003.

According to Lucca, (2008), today the United States has state laws, such as the Forgetfulness Act, in which the postage must be removed from the air, if required, but not all States have adhered to this law. In turn, the North American Chamber of Congress approved, in April 2014, the bill for information sharing, the controversial Cyber and Protection Act (Cispa) or HS-35. Cispa allowed, with President Barack Obama's approval, companies to hand over confidential data to the government, without a mandate, without anonymity, without judicial review. This law is not only binding on American citizens, but on all countries, since all computer users who have any relationship with North American companies, using its services, thanks 
According to Lucca, (2008), today the United States has state laws, such as the Forgetfulness Act, in which the postage must be removed from the air, if required, but not all States have adhered to this law. For its part, the North American Chamber of Congress approved, in April 2014, the bill for information sharing, the controversial Cyber and Protection Act (Cispa) or HS-35. Cispa allowed, with President Barack Obama's approval, companies to hand over confidential data to the government, without a mandate, without anonymity, without judicial review. This law is not only binding on American citizens, but on all countries, as all computer users who have any relationship with North American companies, using their services, free or paid, may have their private data collected, submitting to Cispa.

\section{Information Ethics Territory}

The ethical aspects in communication, especially the development of the ethical dimension of Information Competence, must know the fundamental aspects that involve the concepts of ethics and morals; the relationship between ethics and information, as well as the ethics of information and the actions and practices that constitute themes with ethical and moral implications within information activities. The following aspects are presented to be analyzed:

- Conceptual aspects of ethics and morals;

- General concepts on Information Ethics;

- Access and democratization of information;

- Privacy, security and confidentiality of information;

- Intellectual freedom, free expression, freedom of access and censorship;

- Ethics committees.

It is important to inform that the themes mentioned here do not cover all subjects within the ethical interface and informative activities. However, we approach those that we consider most significant for the theoretical-technical framework of the professional who deals, daily, with the ethical aspects proposed by our study.

\section{Conceptual Aspects of Ethics and Morals}

Ethics can be understood as a study or a scientific, philosophical or theological reflection on human behavior, according to the analysis of Valls (1994). The breadth surrounding the understanding of the conception of ethics is what makes it understood, as complex. Ethics is a theoretical conception, which investigates the moral behavior of women and men in society. It guarantees the importance of the scientific approach, with its concepts, hypotheses and theories about moral problems, which brings to light its objective of study: the moral of human facts and acts.

Ethics seen in the light of rationality and objectivity, generates new knowledge that, in turn, must be systematic, methodical, measurable and, whenever possible, verifiable. Ethics loads historical-social experiences to examine moral practices. And, from that starting point, which seeks to understand and determine the essence of morality, its criteria, its principles and its changes (Sánchez Vásquez, 1975).

According to Sánchez Vázquez (1975), studies on ethics can be divided into four doctrines, throughout history:

- Greek ethics (of which philosophers stand out - Socrates, Plato, Aristotle);

- Medieval Christian ethics (religious ethics and Christian ethics);

- Modern ethics (anthropocentric ethics and Kant ethics);

- Contemporary ethics (from Kierkegaard to existentialism, pragmatism, psychoanalysis and ethics, Marxism, neopositivist and analytical philosophy). 
Ethics or moral philosophy emerged in Classical Antiquity and its main exponents were Socrates, Plato and Aristotle. Socrates, by asking questions, challenged the Athenian people to reflect on the origin and essence of the values, customs and obligations they put into practice, thus reaching the starting point, whose values and moral obligations were established: the conscience of the agent moral (Chauí, 2000).

Plato, on the other hand, is characterized by his contemplation of ideas, Being and Good. For him, the virtues (justice, prudence or wisdom, strength or value and hope) should have a socially differentiated value (Valls, 1994). Aristotle is also part of the relationship between Being and Good, but his way of reflecting on ethical issues is marked by the ends that must be aimed at, for man to achieve what is important: happiness. This is defined by a set of goods, governed by three aspects: reason, feeling and living (Valls, 1994).

If, on the one hand, Socrates owes the beginning of moral philosophy, it is Aristotle who owes the distinction between theoretical and practical knowledge, in the conception of ethics. While practical knowledge aims to guide what needs to be done, in order to have a good and fair life, recognizing that all our actions have consequences; theoretical knowledge is that which states that there are beings and facts that are independent of our actions or interferences. Thus, it is possible to give ethics the category of practical knowledge (Cortina; Martinez, 2005).

Aristotelian ethics is the ethics of the virtues that determine human conduct, based on man's rationality (Abbagnano, 2007). In opposition to this concept of ethics, there is the idea of ethics defended by Greek philosophers. For them, thinking about ethics is thinking about a deterministic conception, based on the rational and perfect nature of reality, that is, the nature conceived by reason.

There is also the Epicurean ethics (Greek philosophers), with typically individualistic traits. In this conception, the individual seeks his own good and his virtue, without worrying about the rest of society. Despite the apparent selfishness, ethics is based on utilitarian points, such as, the idea of not harming the other, in exchange for their reciprocity (Nalini, 1999).

However, it was the Aristotelian concept that was later incorporated into Christian ethics, bringing the notion of happiness closer to that of eternal life. In addition, two new ideas were incorporated: duty and intention (Chauí, 2000). Christian ethics is governed by the truths revealed by God, about the way of life of man, within the determinations of that God so that, in the end, the individual obtains salvation and eternal life.

Christian ethics brings equality between men, as a big difference and added an important detail: in a time of great social inequalities, it only applies to the ideal world, that is, the world after death and, in a certain way, it maintains and justifies social inequality. With such arguments, that because they come from God and his supreme character, Christian ethics ends up elevating his norms and conduct, to a level where they are classified, as absolute and unconditional, that is, as a duty (Sánchez Vásquez, 1975). During this period, Saint Augustine and Saint Thomas of Aquino stand out, as figures that refer to God. The preached ethical ideal is to live according to the spirit and life of love and brotherhood (Valls, 1994).

Kant's reflection preaches individual autonomy as an ethical ideal. The author establishes the concepts of categorical imperative and hypothetical imperative, to justify his vision, with man being the center of all, the function of ethics. For the author, the categorical imperative starts from the notion of good, reason, freedom and goodwill and must be considered, the essence of the moral norm, intrinsic to the conscience of individuals, guiding their ethical actions. The hypothetical imperative, on the other hand, is linked to the obligation to carry out something, by reason of reason, acting as advice to individuals (Guimarães, 2014). Modern philosophy takes up the concept of ethics and persists in the innate character of moral ideas. In romantic philosophy, a more radical form of this conception of ethics is formulated, even based on the individual's ability to decide for himself (Abbagnano, 2007). However, over time, ideologies have replaced spiritual, ethical and religious values.

In the 20th century, the return of freedom as an ethical ideal occurs. The notion of ethics linked to a fairer social life and social relations is developed, according to Ana Silva (2014). Valls (1994) 
makes an important reflection on the social ethical thoughts of the 20th century. For the author, the current massification carries a difference: the individual does not behave more ethically, as it is not necessary, since the individual lives amorally. Also, according to the author, due to the fact that the individual is immersed in a context of crisis, ideologies, mass communication, the economy and the State control the individual's "freedom". This condition reduces the number of conscious, participating and critically empowered citizens in society.

According to Frei Betto, (2006). moral values are linked to the ethical attitudes of a particular social group. These are the values that govern our actions and allow us to assess whether they are ethically accepted or not. Values can be framed in the field of morals, while principles, in the field of ethics, translate into ethical principles. In this way, the values represent the good, while the ethical principles, what must be done, to fulfill a certain value.

According to Blackburn (2008), in The Oxford Dictionary of Philosophy, ethics is the study of concepts (good, right, duty, obligation, virtue, freedom, rationality, choice) that permeate the reasoning practical. It can be said that it is about the study of objectivity, subjectivity, relativism or skepticism, inherent to the concepts mentioned above.

Crisp (2011) establishes three reflections on the use of the term ethics, in the Routledge Encyclopedia of Philosophy. The first concerns the use of the term ethics, as a system of values, of certain groups of human beings and their articulations, the concept most studied by Anthropology. The second reflection concerns ethics, as the characterization of a system: the moral system (or morality). In this reflection, it involves notions, such as, right and wrong, guilt and shame, for example. The third reflection is to understand ethics, as inherent in the moral system, referring to real moral principles. The author observes that the main function of philosophical ethics is to make links, between what constitutes ethics or morals, mainly, to understand what happens when people make moral judgments.

It is often observed the use of the word's ethics and morals as synonyms. However, there are authors who distinguish them. The word ethics must be understood, as a knowledge, a reflection, a normative, a "science of conduct". The word moral, in turn, is the object of ethics and generates action proposals for consistent situations and directing moral conduct (Abbagnano, 2007, p.380). It can be seen, according to Guimarães et al. (2008), that ethics and morals have distinct, but complementary and intrinsic positions, especially with regard to the definition of values and the influence of the social context (morality addresses customs, while ethics, reflection on them), comprehensiveness (a micro vision, as a group, is carried out by morals, in contrast, a macro, universalized view is proposed by ethics), the mode of action (on the one hand, moral, based on a type of social pressure and, on the other hand, ethics is directly related, with personal freedom of choice).

The field of ethics is constituted by the values and obligations that determine moral conduct - also described, as ethical virtues or ethical conduct - that are put into practice by the moral or ethical agent or subject. As a moral subject, a person is understood to have the following characteristics: freedom to self-determine his rules of conduct, capacity for reflection and recognition of other moral agents, will and decision-making capacity, in accordance with his conscience, ability to recognize yourself, as the author of actions, of their impacts and consequences (Chauí, 2000).

In the discussion, we inserted two relevant relationships:

- Ethics and the law;

- Professional ethics.

Considering the ethics related to the science of the moral behavior of the individual, in society, and the law, as the science of the rules and laws that regulate life in society, with the mission of ensuring social welfare and justice (Bernardes, 2012), it is possible to indicate four characteristics of approximation, between these two sciences. The first concerns norms, present both in law and in morals, which impose behaviors and disciplines on citizens. The second is the imperativeness with which legal and moral norms are presented, as these are not mere considerations. The third is the 
mission of ensuring welfare and social cohesion and the fourth characteristic is the fact that they are historical forms of human behavior, insofar as they accompany social transformations, from different historical moments (Sánchez Vásquez, 1975; García Ramírez, 1997; Nalini, 1999).

The authors state that there are aspects that differ ethics and law. The sphere of morality is broader than the sphere of law, as it deliberates on all types of relationships and forms of human behavior, while the law focuses on vital relationships, for the State. This condition also demonstrates that ethics is prior to law, since it manifests itself at the time of characterizing man, as a social being, prior to social organizations and the organization of the State. There is also a divergent moral or morals in society but governed by a single state. However, there must be only one legal system (Sánchez Vásquez, 1975).

Another difference related to the fact that the moral life is interior and the legal life exterior. Failure to comply with moral rules can lead the moral agent to an internal reaction of remorse; while non-compliance with legal rules leads to social disapproval by other members of society, to prison. In the criminal sphere it can have effects on property, when referring to the civil sphere, or it can also lead the State to act in an oppressive manner, on behalf of the citizen. For the fulfillment of both norms, there are also differences: moral norms are not officially codified, while legal norms are expressed in forms of laws, codes and acts of the State. As previously said, ethics and law have common elements and divergent elements, and are marked by human behavior, with the sanction of the State, through its norms and laws, in the case of law, and by the nature of morals, which stands out from state sanction in the case of ethics (Sánchez Vásquez, 1975; García Ramírez, 1997; Nalini, 1999).

In relation to professional ethics, it is possible to emphasize that it is a branch that studies human conduct, before professional action. The term professional ethics involves a great theoretical discussion, since, as it is something concrete, about a restricted group of individuals, many authors have unique concepts regarding the use of the term ethics. One of the most appropriate terms is Deontology (Rasche, 2005; Pérez Pulido; Herrera Morillas, 2009).

Deontological discussions are part of the study of applied ethics. Applied ethics, also called "practical ethics" or "social ethics", is characterized by the use of contemporary life terms, combined with an area of ethical discourse. It is a field that seeks to use philosophical traditions and decisionmaking models to resolve practical issues. In this area, we can include professional ethics, legal ethics, sexual ethics, information ethics, among others (Smith, 2001).

\section{Ethics and Information in the Digital Age}

The relationship between information and ethics gained visibility in the 20th century, mainly because "the post-industrial society gave rise to the information and knowledge society, through the perception that information helps in the mobility of forces (ethical-moral) that govern society and interactions between people. However, the study of informational ethics does not only concern the reproductive research sector of traditional models of ethics, but seeks new methodological, epistemological and normative alternatives for thinking about the application of informational ethics, through scholars around the world.

The need to think about new alternatives for studies in informational ethics to the detriment of classical currents, such as deontology and utilitarianism, which refer to the inability of the former to investigate issues of a virtual nature, such as cybercrimes, pedophilia, prejudices race, gender, religion, territoriality, virtual fights between football fans (and sports in general) etc. and the limitation of the second when considering that utilitarian's conceive digital technologies as neutral, being possible to delimit their aspects of goodness or evil, only by the result (Quilici-González, et al, 2010, p.17).

Floridi (2008, p.12) states that: informational ethics is ecological ethics, something more elementary than life, called being - that is, the existence and flourishing of all entities and their global means - and some something more fundamental than suffering, called entropy. The latter does not refer to the physicists' concept of thermodynamic entropy. Entropy here refers to any type of destruction and corruption of informational objects [...] that is, any form of impoverishment of the being. 
Informational ethics is, on the one hand, the modern scientific study of ethics linked to information (which classical philosophers did not do) and, on the other hand, the moral behavior of subjects with regard to the use and appropriation of information, in several physical and mainly virtual spaces including information and communication technologies that affect subjects in their moral practices.

The influence of information and communication technologies for the formation of people's conscience and morals establish a look between the being and the being, while the production of the global ethics of information (macro ethics) is valued. To this end, the constitution of informational ethics as macro ethics seeks to "[...] analyze informationally all the entities involved (including the moral agent) and their changes, actions and interactions, by treating them, not as separate, but as part an informational medium, to which they belong as informational systems in themselves" (Floridi, 2008, p.10).

Informational ethics has an essential characteristic, which is to verify, how information helps in the production of people's senses and moral behaviors, as well as, it is necessary to consider the direct association between people (being) and beings (technological means), as phenomena of action, interaction and socio-cognitive changes, this association being a vital assumption to think about how information, through digital technological means, interferes in the moral action of information people.

Informational ethics is the "ethics of the outside world", of how the interactions between the subject and the universe take place and how these interactions contribute to the development of the subjects' moral actions. Information and the various informational objects start to play a central role in mediating interactions to the extent that they have moral value, are situated as a space of communication and production of knowledge and interfere in the social life of the subjects attesting that the informational objects mean " a structure of appropriate data that constitute your identity and a set of operations, functions or procedures, which are activated in your relationship with the environment "(FloridI, 2008, p.10-11).

The change of object from traditional ethics to informational ethics resides in the following aspects:

- Concentration of studies on the impact of the means of digital development in different spheres (digital networks, digital communities, digital censorship, digital identity, free access to knowledge, etc.), since it allows the multiplicity of interactions in time space;

- Cultural changes in which the world moves from intercultural relations promoting the configuration of new informational values related to anxiety, emotion, instant and random advertising of contents, the subject's need to express himself publicly, without direct physical contact with other subjects, the need to have the shared ideas, proving that digital identity presupposes the realization of social identity;

- Informational ethics is intercultural and implies that the other is a sine qua non requirement for understanding the di;

- Informational ethics is intercultural and implies that the other is a sine qua non requirement for understanding digital development that the other is always another concrete, historical, situated with all its cultural background and its diverse fundamental affects.

The two types of informational ethics complement each other in that the first analyzes informational support, as a support structure to produce information, while the second delineates the interaction itself between the subjects of information, at the digital level. These two types of ethics allow, in an articulated way, to think about studies on digital informational supports and simultaneous socio-digital practices, such as, for example, digital communities and free access to knowledge, which can only be understood within the scope of digital supports (ethics of digital information) and digital communication (informational ethics). 


\section{Privacy and Informational Ethics}

Rainer Kuhlen (in: Capurro, 2005) defines privacy as “informational autonomy”, which consists of people's power of choice, the use of information in the electronic environment. People must have the freedom to search, select, and use information. From the moment that people's autonomy is violated, their own freedom is violated. This is because, according to Beate Rössler, "the autonomy to protect privacy is the basis of freedom, and not the other way around" (Rössler, in: Capurro; Eldred; Nagel, 2012, p. 79). Life that is not determined by the person himself is an infringement of his privacy.

According to Luciano Floridi (1999), the privacy of information is related to the right to life and freedom. "Informational privacy becomes a fundamental and inalienable right, similar to the right to life and freedom". Once the information is made public, it is no longer controlled by the people (to whom it belongs) and becomes a "dead piece of them even handed over to the world".

The source of the social problems arising from the (bad) use of digital technologies is not in its consequences, not even in moral rejections, about issues of personal privacy, but in the lack of care and respect for people. The reason for this phenomenon is that the private data associated with a person are "information packages", in which people are reduced to numbers and mere collections of information, so that human beings are treated as "informational entities".

Personal privacy is the defense of individual information (information that is a constituent part of one's being), in order to avoid a process of alienation and invasion of privacy. The invasion of privacy poses many ethical problems arising from the (mis) use of ICTs and, especially, the Internet, which has a playful nature, which causes the spread of responsibility. The information in the digital environment is immaterial in nature and the environment itself allows remote interaction with "faceless individuals", the crimes committed are not perceived by their practitioners, as something harmful, since cyberspace is seen as different from the world real. Internet users, acting in an "unreal environment", can also see the information as unreal. The reasons that cause cybercrimes (including the invasion of privacy) are linked to what Floridi called "diffusion of responsibility".

\section{Privacy and Informational Ethics in the Context of Social Networks}

Profit marks the backstage of social media interfaces. For-profit companies on social networks, such as Facebook, adopt strategies to attract users' attention to their products and services. According to Eli Pariser, (2012), companies gain the loyalty of Internet users through personalization and content filtering. This is done by requesting and analyzing the personal data of its users (using technologies such as cookies and web beacons).

Once the greatest possible amount of information about their users is gathered, these companies develop personalization algorithms to target ads, services and digital experiences to users, based on an analysis of their profile, thus boosting their sales. "The attempt to find out as much as possible about their users has become the fundamental battle between Internet giants such as Google, Facebook, Apple and Microsoft." (Pariser, 2012, p. 12).

The problem lies, when these digital companies use users' data, without their consent and, in more extreme cases, in order to harm them in some way. The legal contract between digital companies (including social networks) and users is the terms of use, where you have access to privacy policies, cookie policies, use of the data provided, etc. Personalization is based on fraud. In exchange for the filtering service, we give large companies a huge amount of data, about our daily lives [...]. These companies are getting better and better, in the use of this data, to outline their marketing policies. However, we often believe excessively that these companies will take good care of this information, but when our data is used to make decisions that affect us negatively, we rarely find out (Pariser, 2012, p. 20)

According to Michel Foucault, (2013), the "Watch and punish" arguments represent an important contribution to the problem of the invasion of privacy and the power of surveillance of citizens' lives. For Foucault, (2013, p. 202)., The idea of the "all-seeing eye" can be adapted to any type of power (political, judicial, economic, etc.) where there is a watchful relationship of a given entity, 
towards people. And to exercise it, this power takes the form of permanent, exhaustive, ubiquitous surveillance, capable of making everything visible, but with the condition of making itself invisible [...], thousands of eyes posted everywhere, attention to mobile phones and always alert, a long hierarchical network [...]. This incessant observation materializes in a series of reports and records [...] related to people's behavior.

Ferreira (2014), states that surveillance today has taken shape through the private sector. It is possible to observe this application in the way, how digital companies deal with the information of Internet users, since they have great freedom of access to the information of Internet users and, mainly, of users who use their services. According to Rafael Capurro (2005), the concepts of autonomy, individuality and privacy are transformed into "connected individuals". The author states that "beingin-the-world" is equated, in contemporary times, with the idea of "being-in-the-world-shared". For Capurro, (2016), the notion of the ethics of shared knowledge is contiguity, regarding sharing in the non-digital and digital worlds. One world does not end when the other begins, but they alternate constantly. Eldred (2012) states that the boundaries between both worlds are increasingly blurred.

Human interfaces with the cyber world make it fit, like a glove, so that the boundaries between the cyber being-in-the-world and the physical being-in-the-world become increasingly blurred. [...] The two are perfectly intertwined in a unified everyday being-in-the-world. Rafael Capurro (2005) states that the debate around privacy has fostered security measures in the West since the September 11 terrorist attack in the United States.

The protection of privacy, in the context of the control society, is jeopardized by the development of network communication, via mobile phones. "We live in a digital environment, so protecting individual privacy, fundamentally means protecting our digital data." Privacy within the scope of the phenomenology of identity is a phenomenon where the pluralities of human beings are displayed to one another in a shared world. The exhibition is about how they show off and wear "skill masks" (adopt a certain behavior, wear certain clothes, etc.), in order to be seen in the way, how they present themselves and, in a way, to develop their power in the world. The "public personality" of the individual, whatever the mask he presents to others, about who he is, receives a certain reputation, regarding how esteemed the person is, over the years.

For Eldred, (2012), ethics means living in harmony with the ethos of a lifestyle shared throughout history by a people. This implies that an individual's reputation corresponds to an attack on his private life. With the Internet, the possibilities of revealing your identity have grown exponentially, as well as the ways to track the digital activities that you want to recover, through a consultation with the network's matrix, which records any and all digital movements; making it easier to hurt someone's reputation.

Forms of self-presentation in cyberspace have grown, also the actions that cause cybercrimes have more "chances" of being effective in the digital environment, than in the non-digital one. All action in cyberspace is improved when compared to actions in the physical world. Our digital identity consists of answering the question about who we are in cyberspace. In this context, we are digital data that need ethical and legal protection. "The right to be left alone" is associated with the protection of privacy, within the scope of cyberspace.

Daniel Nagel (2012, p. 124) says that the individual's freedom presupposes that he has opportunities to choose how, when and where he wants to reveal his identity, to the shared world, and that this issue must be a concern of the State, in regards national security. The right to personal and family privacy means, according to the author, that an individual has the freedom to decide both the manner, how he wishes to reveal it, when to hide his information. This freedom also includes the power of choice, about how, the individual wishes to interact with others, in a world that is increasingly connected and shared.

\section{Ethical and Social Responsibility}

Ethics is an area of interest for information professionals, we identify the factors that demonstrate the evolution and that expand the professional attributions and that influence their behavior in 
the performance of such attributions. According to Du Mont, (1991, p. 24), the responsibility of information professionals was focused on individuals or groups with information needs. It categorizes assignments into four stages: a set of information available on the Internet for consultation, employees, users of information and finally society, who are led to think about ethical problems.

In the first stage, professionals are responsible for the set of information available on the Internet for consultation; in the second stage, they must be concerned with the employees who are in the institution, with the human side, since organizations want to have competent professionals who help them in the development of working conditions; in the third stage, the responsibility of information professionals expands to users who need information with good services, with an excellent relationship with users, and, finally, the fourth stage reaches its peak, the issue in which professionals of information really understand the correct interpretation of social responsibility. At this stage, professionals are led to think about ethical dilemmas and reverse their responsibility for the development of society (Du Mont, 1991).

The production, collection, classification and dissemination of digitized knowledge and information (eg documents) raise ethical challenges, such as: How to guarantee a democratic right of access to knowledge and information? What kind of digitalized knowledge and information should they create? How is the integrity and sustainability of this digitalized knowledge and information guaranteed in economic, technical and cultural terms? Who are the beneficiaries of these value-added services?

The main characteristics of added value of digitized knowledge and information are:

- Access to digitized knowledge and information (eg documents) regardless of time and space;

- Combination of documents of different types in different files (digital and / or classic);

- Search for documents and non-digital information based on online search engines and catalogs;

- Combination of information and communication processes.

The main technical and organizational problems related to the creation of digital knowledge and information concern: formats (such as pdf, HTML or gif); content (special collections); sustainability (preservation of digital material; substitutes for fragile originals); copyright (producers, institutions, users); proper use; financing; Cataloguing; research resources. Information specialists must have the skills to structure, represent and update all types of information in different media (Lesk 1997, Borgman 2000).

The ethical issue related to the availability of digital information varies according to the interests of political, economic, religious and military powers. Cultural and moral traditions also play an important role with regard, for example, to what is considered offensive. The main ethical issue in this area has to do with the limits to intellectual freedom; the desire to exclude "bad" information is an ethical paradox, insofar as any exclusion that limits intellectual freedom must be avoided. There is a trend in liberal societies. But this leads to ethical, moral and legal conflicts (Froehlich 1997, Frické / Mathiesen / Fallis 2000).

The protection of intellectual property is one of the most important and difficult ethical, moral and legal issues in the field of information. Different moral and legal traditions have led to different protection laws in different regions of the world. European tradition emphasizes authors' moral rights. They are related to the person of the author and concern the integrity and authorship of his work, as well as his reputation. Anglo-American tradition emphasizes ownership or economic rights (copyright). Conflicts arise when national and international laws and moral traditions protect different aspects of various media.

Harmonization forms are the Berne Convention (1886, revisions) and the Universal Copyright Convention (1952) (UCC). Both treaties are administered by the World Intellectual Property Organization (WIPO). Scanning makes it easy to copy and reform. Internationalization via the Internet changes the dimension and perspective of national legislation and control. This new situation raises questions, such as: should information always be considered, as property? should the notion of 
knowledge sharing become prevalent over the notion of ownership? Can public access to electronic information be guaranteed?

Ethical issues related to the dissemination of information are related to public access problems and referral / brokerage services. The issue of access can be studied, both as an individual and as a social issue. Individuals and society are interested in free access to information. At the same time, it must be recognized that information is a product of work and has an economic value that must be protected. The question is: what the information is and for whom should it be free. The issue of access, as a social issue, concerns the problem of creating equal access opportunities, avoiding the gap between the rich and the poor in information (digital divide).

It is controversial how the discourse on the digital divide can lead to confusion (theoretical and practical) between what can be seen, as a social need, but not as a (human) right. The latter statement ends up expanding the government's power to legitimize its control and government activities (Foster, 2000). About referral / brokerage services, ethical conflicts may arise, for example, in relation to the right to confidentiality. Organizations can ask information professionals to break confidentiality. Information workers must inform their users about the limits of their sources and methods. Finally, there is the issue of misinformation (or bad information practice) that can cause great (economic) damage to users.

\section{Right to Privacy and Anti-Terrorism Policies}

States, when dealing with anti-terrorism policies, argue that their ability to prevent and investigate acts of terrorism is strongly related to the increase in surveillance powers. Most of the anti-terrorism legislation, following the September 11, 2001 terrorist attacks, has focused on increasing government surveillance powers. States consider that, because terrorism is a global issue, the search for terrorists cannot be limited across national borders, so that third party assistance, potentially in possession of extensive amounts of information about individuals, is a rich resource to identify and manage terrorism suspects.

States that do not have constitutional or legal safeguards have been able to expand surveillance laws, with only a few restrictions. Countries that have such constitutional and legal safeguards, governments question the protection of the right to privacy by failing to apply and transform existing safeguards, by virtue of cooperation with third countries or with private ones, or by replacing domestic surveillance systems with other extraterritorial ones

States make use of specific legal surveillance measures, but only if it is a well-founded process situation or if there are reasonable grounds and in absolute respect for human rights. The law requires that there be a factual basis, related to an individual's behavior, that justifies the strong suspicion that he is involved in criminal activities.

In recent years, we have witnessed an increase in the surveillance of communications, information services and law enforcement agencies around the world, due to the undeniable importance of new information and communication technologies (for example, "Eavesdropping" and surveillance technologies that can access the geographical position of mobile phones, the technology that informs governments about the content of private text conversations, of Voice over Internet Protocol (VoIP) users, or that installs programs spies on suspects' computers to allow remote access to computers). In some countries, encryption technologies have been banned, which make communications more secure but more difficult to intercept.

States have increased their activities of identifying, evaluating and labeling the general public, under the excuse of "measures to combat terrorism". Thus, they use various techniques (installation of Line interceptions - including any types of telephone: fixed, cellular, mobile, oral - including microphone, Electronic - including digital pager, fax, computer, combination, detained persons and convicted persons who may violate the right to privacy of the individual: when surveillance takes place in public places and refers to broader groups of people, surveillance actions are subject to weaker authorization and judicial supervision regimes. 
Existing human rights standards have been relaxed, twisted and broken, through the use of interceptions and searches, through the expansion of surveillance of finances, communications and travel data, through the use of profiles to identify potential suspects, through compilation of several lists and databases to calculate the probability of suspicious activities and to identify individuals considered likely to be subject to greater surveillance. During the past few years, even more innovative techniques have been applied, such as the collection of biometric data or the use of body examiners who can see through clothing.

The general alarming trend is for States to increase their powers to intercept, question, inspect and identify individuals and, at the same time, reduce internal legal controls to prevent the misuse of these powers. These powers have given rise to concerns about ethnic profiles and discrimination in several countries and concerns that these new powers will cause serious tensions between citizens and the state.

\section{CONCLUSION AND CLUES FOR FURTHER INVESTIGATIONS}

Digital culture does not mean that the culture of the book disappears. Different media with different qualities are not substituted, although they can displace their use for specific purposes. Likewise, oral culture did not disappear with the invention of writing or with the massive dissemination of printed works. Today, we are particularly aware that virtual communities and distance learning make the specific value of meeting people personally more evident.

The information economy is growing, and its creation is supported by utilitarian ethics, as a way to improve well-being, regardless of degree and nature, in the ways of using digital information, since economic growth depends basically on the knowledge. Intellectual capital, externalized in any type of artificial media, is crucial for economic and social development.

The massive diffusion of ICT's causes radical changes in public and private institutions, as well as in national and international information and communication policies. This may involve:

- The creation of specialized (regional) knowledge markets;

- The development of digital libraries and archives (national and / or regional);

- The development of electronic commerce;

- The publication and dissemination of scientific knowledge over the Internet;

- The creation of public Internet access services;

- The creation of educational services based on ICT's (at different levels: schools, universities, research, etc.);

- The promotion of local cultures in the digital environment;

- The development of communities and interest groups, regardless of geographical boundaries;

- The participation of individuals and groups in political processes (community, regional, national, international);

There are several types of barriers that can cause users to be excluded from the benefits of new technologies, such as:

- Economic barriers: Energy, telephone, servers, hardware and software;

- Technical barriers: Acquisition, use and upgrade costs;

- Cultural barriers: Illiteracy of information (Bawden 2001), mastery of English.

Justice and equity in the information field, following the contractual approach to ethics, concern the creation of a social information and communication and market economy. In other words, digital 
capitalism must be viewed ethically, as a challenge for creating (legal) conditions in order to overcome the so-called digital divide (US Department of Commerce 1999).

Public libraries can play a fundamental role, allowing free access to the Internet to people who, for different reasons, cannot use ICTs, but are dependent on this type of device to shape their lives. Libraries can become an agent of social change, following the service ethics approach, promoting educational, social and economic activities, at all levels of society.

It is noticed that the agenda of the right to privacy protection on the Internet, does not gain due visibility, in face of the growing problems involving this theme, today; This is aggravated by the reality of personalization and content filtering actions, operated by digital companies to enhance profitability, facilitating the broad access they have to Internet users' information, which limits freedom and autonomy in this environment.

Internet users' digital experiences cannot be characterized by the principles of freedom and autonomy, since their privacy is not treated as a priority by digital companies. Such companies do not pay attention to the phenomenon of the right to privacy, but are mainly concerned, with the development of marketing policies for the purpose of profit, a controversial game between transparency and lack of privacy.

The reality of the culture of transparency in an increasingly connected and shared world, it appears that Internet users have the habit of investigating (and evaluating) each other's private data, activities and behaviors, surpassing the notion that control actions and invisible surveillance of networks, they would be only of companies, being present also among the individuals themselves.

In this society, the oppressive figures of the punitive and controlling institutions become dispensable, since people assume the role of sentinels and executioners of each other and of themselves. It is exclusively up to the individual to choose when, how and what to reveal and / or hide information about his private life and that of his family. Failure to guarantee this right is a matter for the State. Personal data consists of the very digital identity of Internet users, it is necessary to guarantee the protection, both ethical and legal, of such data, in order to protect the digital identity of Internet users.

The dissemination of digitalized knowledge and information raises ethical challenges, such as: How to guarantee the democratic right of access to knowledge? Can digital libraries replace existing traditional libraries? What kind of public and private services should be offered? What kind of digital collections should be created? How is the integrity and sustainability of these collections guaranteed economically, technically and culturally?

The article summarizes the existing academic works and generates new knowledge. Reflects on: What is the relationship between the right to freedom of expression and the right to privacy on the internet? Is it possible to have freedom of expression, access to information, without being constrained? Are we exchanging freedom for privacy and security? Is the solution just in regulation and technology? To conclude the implications for future research. 


\section{REFERENCES}

Blackburn, S. (Org.). (2008). The Oxford Dictionary of Philosophy (2nd ed.). Oxford University Press. Available from: https://www.oxfordreference.com/view/10.1093/acref/9780199541430.001.0001/acref9780199541430

Borgman, Ch. L. (2000). From Gutenberg to the global information infrastructure: access to information in the networked world. MIT Press.

Cabral, B. F. (2010). Freedom of speech - Considerations on freedom of expression and the press in American law. Obtained from Jus.com.br: https://jus.com.br/artigos/17476/freedom-of-speech

Cajazeiras, J. E. R. (2006). The importance of social responsibility in management: Interview. Gerenciais Magazine, 5, 51-62.

Câmara, M. A. (2005). Telecentros as an instrument of digital inclusion: Comparative perspective in minas gerais (Master's dissertation). Federal University of Minas Gerais. Available from: Error! Hyperlink reference not valid.

Capurro, R. (2001). Ethics and information in the digital age. In Annual Course And Conference In Libraries In The Digital Age, 2001, Dubrovnik (Croatia). Anais (pp. 1-8). University of Zagreb. http://www.capurro.de/ lida2001.pdf

Capurro, R. (2003). Epistemology and Information Science. In National Research Meeting In Information Science, Belo Horizonte. Anais... (p. 5). ECI/UFMG.

Capurro, R. (2009). Intercultural ethics of the información. In Ethics in society, in the area of information and professional activity: the view of Philosophy, Sociology, Information Science and the training and professional practice of the librarian in Brazil (pp. 43-64). Federal Council of Librarianship. Available from http://www. cfb.org.br/popup/a_etica.pdf

Capurro, R. (2010a). Desafíos teóricos y prácticos de la ética intercultural de la información. In Information ethics: concepts, approaches and applications (pp. 11-51). Idea.

Capurro, R., Eldred, M., \& Nagel, D. (2012). It and privacy from an ethical perspective digital whoness: identity, privacy and freedom in the cyberworld. In Internet Privacy: multidisciplinary analysis. Available from: http://www.acatech.de/fileadmin/user_upload/ aumstruktur_nach_Website/Acatech/root/de/Publikationen/ Projektberichte/ acatech_STUDIE_Internet_Privacy_WEB.pdf

Capurro, R., Bothma, T., \& Britz, J. C. (Eds.). (2010b). Africa reader on information ethics. Pretoria: University of Pretoria.

Crisp, R. (2011). Ethics. In Routledge Encyclopedia of Philosophy. London: Routledge. Available from: https:// www.rep.routledge.com/article/L132

Da Silva, A. M., \& Ribeiro, F. (2002). From the Documentary "sciences" to information science: epistemological essay for a new curricular model (1st ed.). Affront Editions.

Du Mont, R. R. (1991). Ethics in librarianship: A management model. Library Trends, 40(2), 201-215.

Edward Snowden. (n.d.). Obtained from Wikipedia: https://pt.wikipedia.org/wiki/Edward_Snowden

Fallis, D. (2007). Information ethics for twenty first century library professionals. Hi Tech Library. Available from: http://www.emeraldinsight.com/doi/pdfplus/10.1108/07378830710735830

Ferreira, R. d. S. (2014). The surveillance society as a society of discipline, surveillance and control. Información, cultura y sociedad. Available from: http://www.scielo.org.ar/scielo.php?script=sci_arttext\&pid $=\mathrm{S} 185117402014000200007$

Finkelstein, M. E. (2011). E-Commerce Law (2nd ed.). Rio de Janeiro: Elsevier.

Fleury, M. T. L. (2000). Managing Cultural Diversity: Experiences of Brazilian Companies. Business Administration Magazine.

Floridi, L. (1999). Information ethics: On the philosophical foundation of computer ethics. Ethics and Information Technology. 
Floridi, L. (1999). Information ethics: on the philosophical foundation of computer ethics. Ethics and Information Technology.

Floridi, L. (2008a). Information ethics: a reappraisal (Vol. 10). Ethics and Information Technology. Available from http://www.philosophyofinformation.net/publications/pdf/tpoi10yl.pdf

Floridi, L. (2008b). Information ethics: its nature and scope. In J. Van Den Hoven \& J. Weckert (Eds.), Moral philosophy and information technology (pp. 40-65). Cambridge University Press.

Floridi, L. (2010). The philosophy of information: ten years later. Metaphilosophy. Available from: http://www. philosophyofinformation.net/publications/pdf/tpoi10yl.pdf

Foley, J. P. (n.d.). Ethics on the internet. Obtained from La Santa headquarters: http://www.vatican.va/roman curia/pontifical_councils/pccs/documents/rc_pc_pccs_doc_200202 28_ethics-internet_po.html

Foster, S. P. (2000). The Digital Divide. Some Reflections. The International Information \& Library Review, 32(3/4), 437-451. doi:10.1080/10572317.2000.10762529

Foucault, M. (2013). Watch and punish: history of violence in prisons. 41. Voices.

Freire, I. M. (2001). The social responsibility of information science and/or The look of possible consciousness about the scientific field (Doctoral thesis). Brazilian Institute of Information in Science and Technology (IBICT) and the Federal University of Rio de Janeiro (UFRJ). Available in: https://ridi.ibict.br/bitstream/123456789/682/1/ isafreire2001.pdf

Freire, I. M. (2010). Reflections on an ethics of information in networked society. Access Point. Available in: https://portalseer.ufba.br/index.php/revistaici/article/view/4518/3567

Freire, I. M. (2010). The possible awareness for an information ethics in networked society. In Information ethics: concepts, approaches, applications (Vol. 1, pp. 123-141). Idea. https://repositorio-aberto.up.pt/ bitstream/10216/26301/2/armandomalheiropesquisa000107223.pdf

Freire, I. M. (2013). Thematic 'social responsibility' in the literature of Information Science indexed by Brapci. In XIV National Meeting of Research in Information Science, 14, 2013, Florianópolis. Anais Eletrônicos... Florianópolis: UFSC. Available in: http://enancib.ibict.br/index.php/enancib/xivenancib/paper/view/4004/3127

Freire, I. M., Silva, A. L. d. A., Nascimento, \& Lima, G. F. C. d. (2015). The mandala of the virtues of librarianship. RBBD - Brazilian Journal of Librarianship and Documentation, 5. Available in: https://rbbd.febab.org.br/rbbd/ article/view/347/401

Freire, I. M., \& Silva, J. T. (2013). A mandala das virtudes da Arquivologia: pesquisa report. Mr. Archeion. Available in: http://www.ies.ufpb.br/ojs2/index.php/archeion/article/view/17125/9748

Freire, I. M. A. (2010). Planetary utopia of Pierre Lévy. InCID: Journal of Information Science and Documentation. Available in: https://www.revistas.usp.br/incid/article/view/42324/45995

Freire, G. H. d. A. (2010). On information ethics. Brazilian Symposium on Information Ethics, 1.

Froehlich, T. (2017). A not-no-brief account of current information ethics: The ethics of ignorance, missing information, misinformation, disinformation and other forms of deception or incompetence. BiD: universitaris texts de biblioteconomia i documentació. Available in: http://bid.ub.edu/en/39/froehlich.htm

Froehlich, T. J. (1995). Ethics and information. El Profesional de la Información. Available from: http://www. elprofesionaldelainformacion.com/contenidos/1995/septiembre/tica_e_infor macin.html

Froehlich, T. J. (2004). A brief history of information ethics. Universitaris texts of Librarianship i Documentació. Available from: http://www.ub.es/bid/13froel2.htm

García Ramírez, S. (1979). Ética y derecho. In Los valores en el derecho mexicano: una aproximación. Mexico, D. F.: Fondo de Cultura Económica: UNAM. Available from: http://biblio.juridicas.unam.mx/libros/2/756/45.pdf

Gonzáles De Gómez, M. N., \& Cianconi, R. de B. (Org.). (2017). Information ethics: perspectives and challenges. Niterói: PPGCI/UFF. Available in: https://www.researchgate.net/publication/319275884_ETICA_ DA_INFORMACAO_perspectivas_e_desafios 
González De Gomez, M. N. (2009). Contemporary challenges of information science: the ethical issues of information. National Research Meeting of the National Association of Research and Graduate Studies In information Science, 10. Available from: http://enancib.ibict.br/index.php/enancib/xenancib/paper/viewFile /3133/2259

González De Gómez, M. N. (2012). Information regime: construction of a concept. Information \& Society: Studies. Available in: https://periodicos.ufpb.br/ojs/index.php/ies/article/view/14376/8576

González De Gómez, M. N. (2001). For an epistemological reflection on Information Science. Perspectives in Information Science.

Google Scholar. (n.d.). Available in https://scholar.google.com.br/

Guimarães, J. A. C. (2008). Ethics in information activities: theoretical aspects. Access Point. Available from: http://www.portalseer.ufba.br/index.php/revistaici/article/view/2670

Guimarães, J. A. C. (2014). Presentation. In Ethical practices in libraries and information services: Brazilian investigations. Rio de Janeiro: Interscience.

Irish Data Protection Commissioner. (2009). Case Study 1: Disclosure of personal data due to inappropriate security measures. Author.

Lesk, M. (1997). Practical digital libraries: books, bytes and bucks. Morgan Kaufmann.

Navarro, A. M. N. d. P. (2014). Informational Privacy: Origin and Foundations in American Law. Available in http://www.publicadireito.com.br/artigos/?cod=34f9a343f945196b

Nissembaum, H. (2011). A contextual approach to privacy online. Journal of the American Academy of Arts $\&$ Sciences, 140(4).

Nissenbaum, H. (2010). Privacidad amenazada. Tecnología, política y la integridad de la vida social. Ocean.

Pariser, E. (2012). The invisible filter: what the internet is hiding from you. Zahar.

Privacy International (PI). (n.d.). www.privacyinternational.org

Privacy.Org. (n.d.). https://privacy.org/

Pulido, M. P. (2009). La profesión en información y documentación. Educación y Biblioteca. Available from: https://gredos.usal.es/jspui/bitstream/10366/119625/1/EB21_N170_P78-82.pdf

Pulido, M. P. (2007). Cinco preguntas acerca de los códigos deontológicos para los profesionales en biblioteconomía y documentación. Educación y biblioteca. Available from: https://gredos.usal.es/jspui/ bitstream/10366/119362/1/EB19_N159_P102-106.pdf

Quilici-Gonzalez, J. A., Kobayashi, G., Broens, M. C., \& Gonzalez, M.E.Q. (2010). Ubiquitous computing: any ethical implications? International Journal of Technoethics.

Rasche, F. (2005). Ethical issues for librarians. ACB Magazine: Librarianship in Santa Catarina, Florianópolis, 10(2), 175-188. Available from: https://www.brapci.inf.br/_repositorio/2010/06/pdf_f564ebbc35_0011137.pdf

Rasche, F. (2014). Reflections on ethics in professional practice in public libraries. In Ethical practices in libraries and information services. Brazilian investigations.

Report says internet freedom falls for the seventh consecutive year in the world. (2017). Obtained from News Journal: https://www.dnoticias.pt/mundo/relatorio-dizque-liberdade-na-internet-cai-pelo-setimo-anoconsecutivo-no-mundo-FA2354557

Sá, A. L. (2007). Professional ethics. Atlas.

Sampaio, J. A. L. (1998). Right to intimacy and private life. Del Rey.

Sharma, P. (1987). Libraries and society. Ess Publications.

Silva, A. C. P. O. Da, (2014). It is necessary to be aware: ethics in the expressed thinking of community library leaders. Curitiba: Appris. 
Silva, A. K. L. (2008). Plagiarism in the academic environment: how graduate students understand the theme. Contemporary Perspectives, Campo Mourão, 3(2), 117-135.

Silva, A. M. da. (2006). The information: of the understanding of the phenomenon and construction of the scientific object. Port: Affront/CETAC Editions.

Silva, R. da. (2014). Intellectual property and plagiarism: A first panel. Salvador: EDUFBA.

Silveira, P. A. (1997). Data protection in Comparative Law. AJURIS Magazine, 71.

Smith, M. M., (2011). The beginnings of information ethics: reflections on memory and meaning. Journal of Information Ethics.

Smith, M. M. (2001). Information ethics. In Advances in Librarianship. Bingley: Emerald Group. doi:10.1016/ S0065-2830(01)80019-2

Targino, M. d. G. (2006). The profession of librarian in Brazil. In Looks and fragments: daily library and information science. Teresina: EDUFPI.

The Constitution of the United States of America. (1787). A Brief History of Human Rights - and the Bill of Rights. Obtained from United for Human Rights: https://www.unidosparaosdireitoshumanos.com.pt/what-arehuman-rights/briefhistory/declaration-of-independence.html

The Magna Carta. (1215). A Brief History of Human Rights. Obtained from United Human Rights: https://www. unidosparaosdireitoshumanos.com.pt/what-are-humanrights/brief-history/magna-carta.html

United Nations. (1945). A Brief History of Human Rights. Obtained from United for Human Rights: https://www. unidosparaosdireitoshumanos.com.pt/what-arehuman-rights/brief-history/the-united-nations.html

United Nations. (2009). Report of the Special Rapporteur on the promotion and protection of human rights and fundamental freedoms while countering terrorism. Author.

United Nations. (1948). The Universal Declaration of Human Rights. Available from: https://www.un.org/en/ universal-declaration-human-rights/

Universal Declaration of Human Rights. (n.d.). Available from: http://www.dhnet.org.br/direitos/deconu/textos/ integra.htm

Universal Declaration of Human Rights. (n.d.). Obtained from United Nations Human Rights - Office of the High Commissioner: https://www.ohchr.org/EN/UDHR/Documents/UDHR_Translations/por.pdf

Universal Declaration of Human Rights. (n.d.). Obtained from Wikipedia: https://pt.wikipedia.org/wiki/ Declara\%C3\%A7\%C3\%A3o_Universal_dos_Direitos_Humanos

Varela, F. (1995). About ethical competence (70th ed.). Academic Press.

Veloso, L. H. M. (2006). Ethics, values and culture: specificities of the concept of corporate social responsibility. In Ethics and social responsibility in business (2nd ed.). Saraiva.

\section{ENDNOTES}

1. The Semantic Web is the Data Web, that is, it attributes meanings to information on the web, identifying and organizing it, which enables an environment of cooperation between men and machines. Available from: <https://tableless.com.br/a-web-semantica/>. Accessed: 20 Oct. 2016. "Everyone has the right to freedom of opinion and expression; this right includes freedom to hold opinions without interference and to seek, receive and impart information and ideas through any media and regardless of frontiers." (UNITED NATIONS, 1948)

"Everyone has the right to respect for his private and family life, his home and his correspondence."

"Privacy-protecting autonomy is the basis of freedom, not the other way round."

"Informational privacy becomes 'a fundamental and inalienable right' akin to the right to life and liberty." "[...] it is transformed into a dead piece of my self that has been given to the world [...]." 
There are several computer crimes that worry the authorities today. Some examples are plagiarism, hacking, identity theft, virtual harassment, online harassment, invasion of privacy, among others. Available from: <http://www.enigmasoftware.com/en/5-popular-cybercrimes-as-avoidsthem-easily/>. Accessed: 15 Oct. 2015.

8. Cookies are text files that store users' preferences across multiple websites. Web beacons allow websites to collect and transfer information to users when they click on an image. These technologies are tracking tools used by websites to know user profiles. Available from: <http://seguranca.uol.com.br/antivirus/ dicas/curiosidades/privacidade-na-internet-conheca-oscookies-web-beacons-e-flash-cookies.html\#rmcl> . Accessed: 15 Oct. 2016.

Jose Poças Rascão (PhD, ISCTE/ULI) is a Professor of Management Information Systems at the Polytechnic Institute of Setubal, Graduate School of Business Sciences, Portugal. It is research in the Research Unit in the development of enterprise (UNIDE) at the Lisbon University Institute (ISCTE / ULI). Since 2000 he has published 15 books and over 80 research papers in international scholarly academic journals, about on management strategy and management of information. Under his supervision, 17 Masters Theses have been successfully from 2007 to 2018. From 2010 to 2015 was Director of Course Management of Distribution and Logistics. From 2013 to 2014 was Coordinator of Research Center, Polytechnic Institute of Setubal, Graduate School of Business Sciences. From 2000-2004 was Information Systems Management Course Coordinator Polytechnic Institute of Setubal, Graduate School of Business Sciences. He also works the private Management Consultant for large and medium-sized enterprises. He worked the Management Consult at Price Waterhouse and Coopers \& Lybrand between 1989 and 1995. 